\title{
Romanian pastures - Concept, Legislation and Management
}

\author{
Nicușor SIMA ${ }^{1}$, Valentin MIHAI ${ }^{2}$, Doru CRISTE ${ }^{1}$ and Rodica SIMA ${ }^{2 *}$ \\ ${ }^{1}$ Faculty of Animal Husbandry and Biotechnology, University of Agriculture Science and Veterinary \\ Medicine Cluj-Napoca, Romania \\ ${ }^{2}$ Faculty of Horticulture, University of Agriculture Science and Veterinary Medicine Cluj-Napoca, \\ Romania; \\ * corresponding author: rodiganea@yahoo.com
}

Bulletin USAMV series Agriculture 72(1)/2015

Print ISSN 1843-5246; Electronic ISSN 1843-5386

DOI 10.15835/buasvmcn-agr: 10655

\begin{abstract}
Romania as EU member country has the obligation to respect both the assumed commitments and the new regulations concerning the management of payments to farmers. An example in this respect is the legislation in the field of pastures. A transdisciplinary approach of proposed changes for pastures low is compulsory in order to harmonize conceptual problems with technical and juridical problems.
\end{abstract}

Keywords: law of pastures, multifunctionality, payments.

\section{INTRODUCTION}

Romania, as an EU member state is obliged to comply with such commitments and regulations on the new management of payments to farmers. In this respect, it is highly required to apply measures such as an update of sites and further harmonization of national legislation in the field of agriculture to that required by the new CAP. An example is the pasturelands legislation. Changes to the law have sought to allow grassland management to be the responsibility of livestock farmers by strengthening farm practices towards sustainable and multifunctional agriculture.

\section{AIMS AND OBJECTIVES}

Livestock farming and fodder production from pasturelands are considered to be activities of national importance under the Animal Breeding Law 72/2002 and the Organization strategy on the improvement and use of pasturelands 235/2003 nationwide. Pastures used for these activities are, as appropriate, public or private property and are assets of real national interest, in accordance with Law 214/2011 on the organization, management and exploitation of grasslands. In order to repair the existing legal and technical discrepancies in these documents a new document was submitted and approved, Law 34/2013, known as the law of pasturelands. Its application imposed the development of new methodological standards and the introduction of amendments. Knowledge, understanding and acceptance by stakeholders of the measures and amendments submitted and adopted in these documents allow proper deployment and easy management of grasslands. A transdisciplinary approach is required for these particular amendments to harmonize conceptual issues with the technical and judicial ones.

\section{MATERIALS AND METHODS}

Clarification of current types of pastureland management that condition the subsidies or payments for owners or users of these pastures has demanded the study and comparative analysis of national legislation in the field of pasturelands, of EU Regulations on the granting of pastureland payments, and a number of conceptual approaches related to the concept of pastureland and its manner of employment. 


\section{RESULTS AND DISCUSSION}

Conceptually, grassland classification refers to their origin, their introduction into agricultural crop rotation system and their use. According to their origin, there are natural grasslands covered by spontaneous herbaceous vegetation. They are subdivided into primary natural meadows where the original and current vegetation was and is grass and secondary natural meadows where the original vegetation was represented by woody species resulted from human activities (deforestation, burning, grazing, mowing) followed by the installation of spontaneous herbaceous vegetation. In our country the first category occupies small areas and is represented by alpine meadows and grasslands of the steppe. Most of the grassland in Romania is the secondary grasslands, which require careful management to maintain good forage value species or species characteristic of habitats of Community interest. According to the manner of installation, herbaceous species in grasslands - can be spontaneous/sown grasslands and according to the inclusion or non-inclusion of an agricultural crop rotation system, they are theoretically classified into permanent grassland and temporary grassland (Bărbulescu et al., 1991).

Temporary pastureland, also called sown pastureland exhibit a finite duration of use of 1-6 years (Vântu et al., 2004) or 2-5 years (Rotar and Carlier 2005). Grasslands are classified according to their use in three categories - meadows, pastures and mixed. As follows, a difference will be reported in the case of pasturelands, occurring between concept and existing laws. A first difference is observed in defining notions of permanent grassland and meadow, which are extended in legislation compared to theoretical concepts. Another difference relates to the manner of understanding of how to grasslands are used. Law $34 / 2013$ mentions explicitly only pastures and hayfields for usage. The legislation details on the links between the three manners of employment of pastures and cadastre. The importance of knowing this relationship is given by the requirement for specific management measures according to the Good Agricultural and Environmental Conditions (GAEC) and Agro-environmental measures that condition the payments to be obtained and the Agrienvironment measures that condition payments. Additionally, the law specifies the potential users of the meadows, which are responsible for their management. Users can be individual/company listed in the National Register of Exploitations (RNE). Another important aspect of the management of pasturelands is their classification by ownership, which is mentioned only in law and indicates four possible situations. Law 34/2013 notes that agricultural areas are considered permanent grassland pasture and meadow, natural or cultured, used for the production of grasses or other herbaceous forage, which were not included in the crop rotation system for at least 5 years. This last statement of the minimum duration of five years is different from the life of a temporary meadows mentioned in specialized literature. Another difference between theory and law refers to the inclusion in the category of consistent wooded grassland meadows (woody vegetation cover) of less than 0.4 . All statements presented apply to permanent grassland located outside city limits.

\section{CONCLUSION}

The differences between theory and law must be analyzed in conceptual and technical terms to use the correct terms and concepts with the same meaning in education and in practice. The need to complete scientific and technical information relating to pasture with some legal elements can be noted. Therefore, both a correct understanding and application of laws is possible, as well as the selection of an appropriate grassland management in accordance with the requirements for receiving payments. Among the provisions of the new law that will exert a strong practical impact on pastureland management of priority is the concession by farmers of pasturelands that are public or private property of local councils and for a concession period of 7-10 years. In these circumstances they will be interested in the sustainable use of grasslands and have the opportunity to benefit from various payments.

\section{REFERENCES}

1. Bărbulescu C, Puia I, Motcă Gh and Moisuc Al (1991). Fodder plants and pasture cultures. Editura Didactică şi Pedagogică Bucureşti. p. 9-77.

2. Rotar I and Carlier L (2005). Pasture cultures. Ed. Risoprint, Cluj-Napoca. p. 12-86.

3. Vîntu V, Moisuc A, Motcă Ghe and Rotar I (2004). Fodder plants and pasture cultures. Ed. Ion Ionescu de la Brad, Iași, $17-57$.

4. Laws 72/2002; 235/2003; 214/2011; 34/2013 